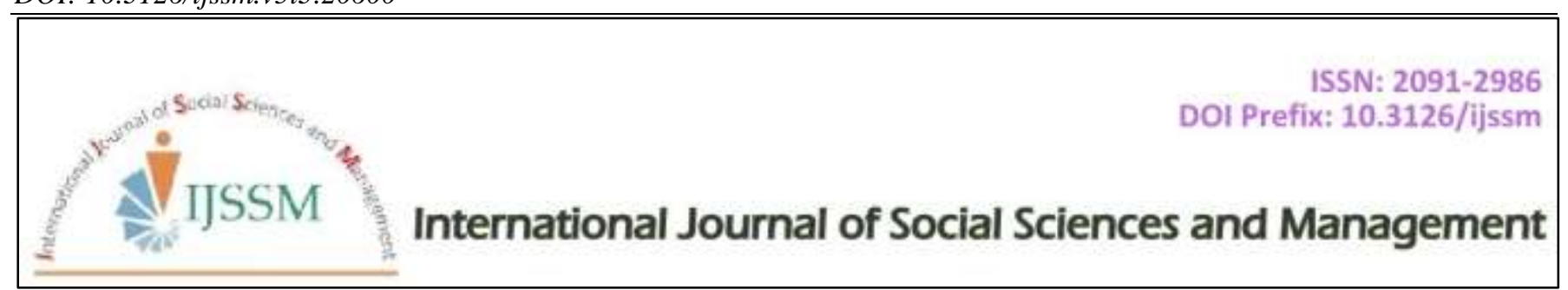

Research Article

\title{
Influence of Poverty on Moral Development in Rural Community Lahore
}

\author{
Razia Parveen $^{1 *}$, Muhammad Hussain ${ }^{1}$, Iram Majeed ${ }^{1}$, Muhammad Afzal ${ }^{1}$, Syed Amir Gilani' \\ ${ }^{1}$ Lahore School of Nursing, The University of Lahore, Pakistan.
}

\begin{abstract}
Background: Poverty is a major social worldwide issue. "Poverty is like punishment for a crime you didn't commit". Poverty as a concept almost uniquely applied to humans. It refers to a condition that causes its victims through lack of economic resources to live lives in which they cannot fully participate in the range of activities expressive of their nature as human beings Moral is a socialized reasoning that develops as a result of the norms of a society and influenced by the culture of that society. Objective: The main purpose of the study is to assess the relationship of poverty and the moral development of community people. Methodology: A co relational study design was use. A small sample of $n=100$ was selected Convenient sampling technique was used for the collection of data. Self-prepared 5 point Likert scale questionnaire adapted from thesis of Solomon Fakinlede (2008). The questionnaire tools was used to get some basic information which includes participant age, marital relationship, and family structure, no of children. After the collection of data, it was enter to Statistical Package for Social Sciences 21 (SPSS). Result: The Results found reveals that the coefficient of correlation rs value of the spears man correlation test is 0.939 , which suggest that there is a positive, strong, linear correlation between the poverty and moral development. Conclusion: In conclusion, it stated that this research study found the relationship between the poverty and moral development in a society. The results revealed that there is a strong positive correlation between the poverty and moral development of the people.
\end{abstract}

Keywords: Poverty; Moral Development; Rural community of Lahore

\section{Introduction}

Poverty is a major social and worldwide issue. Throughout the world millions of people are suffering from poverty and its crippling effects, "Fifty-six percent of the world's population is currently poor: 1,2 billion live on less than $\$ 1$ a day and 2,8 billion live on $\$ 2$ a day" (Aiyedogbon and Ohwofasa, 2012). Although some people who suffer deeply from poverty are victims, others show resilience by making clever plans in their efforts to survive (Thompson, 2017).
"Poverty is like punishment for a crime you didn't commit"(Venera and Zakus, 2016). Poverty as a concept is almost uniquely applied to humans. It refers to a condition that causes its victims through lack of economic resources to live lives in which they cannot fully participate in the range of activities expressive of their nature as human beings, sometimes they may not even be able to maintain their physical health (Nash, 2016).

\section{Cite this article as:}

R. Parveen et al. (2018) Int. J. Soc. Sc. Manage. Vol. 5, Issue-3: 113-124. DOI: 10.3126/ijssm.v5i3.20600

\section{$1 *$ Corresponding author}

Razia Parveen,

Lahore School of Nursing, The University of Lahore, Pakistan

Email: hassanrazia46@gmail.com

Peer reviewed under authority of IJSSM

(C) 2018 International Journal of Social Sciences and Management

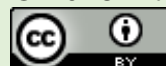

This is an open access article \& it is licensed under a Creative Commons Attribution 4.0 International License (https://creativecommons.org/licenses/by/4.0/) 
To describe someone as poor thus indicates that a person has fallen below the standard of life thought appropriate for a human being in a specific society. The concept of poverty is generally taken to signify two levels at which persons' standard of living might have fallen below that of their peers.(Donnelly and Whelan, 2017)The concept of absolute poverty implies that a person does not have adequate economic capacities to provide food, clothing, shelter, security, and medical care to maintain their physical health. The concept of relative poverty signifies that although people have adequate economic capacities to provide food, clothing, shelter, security, and medical care to maintain their physical health, they cannot participate in any other activities regarded as indicative of being human in their society (Metz, 2016). Pakistan is one of the developing countries facing the extreme level of poverty, having more than one third of its populace living below the poverty line. In Pakistan, for instance, the persons who earn income, which cannot meet the daily intake of about 2350 calories per person, are considering to fall below the poverty line. In Pakistan, lack of access to credit, training in incomegenerating activities, basic social services and infrastructure are critical factors behind the persistence of substantial poverty, especially in under-served rural and urban areas.(Trani and Bakhshi, 2017) Children living in poverty are more likely to learn poor health behaviors and are more susceptible to mental illness as they grow older. Children living in constant poverty also show the worst cognitive development, compared to children from higher socioeconomic backgrounds. Children poor are often unable to participate in social, leisure and celebratory activities, which can negatively affect their self-esteem and friendships. They may feel less able to take advantage of learning opportunities in school, which can eventually hurt their future employment prospects .(Xun and Lubrano, 2017). Moral means idea of development implies that as humans grow older and become more experience, our hold of moral right and wrong also develops.(Gibbs, 2013). Moral judgment: Moral is a socialized reasoning that develops as a result of the norms of a society and influenced by the culture of that society.(Dana and Galbraith, 2016). Moral sensitivities in many contemporary societies require that children be educated by their parents and treated decently so as to ensure that they have opportunities for optimal development as human beings.(Hallett, 2016). Moral personality, we must move beyond early childhood, and even the college years. We must examine the nature of moral maturity (Narvaez and Lapsley, 2014). Moral sensitivities in many contemporary societies require that children be educated by their parents and treated decently so as to ensure that they have opportunities for optimal development as human beings.(Gasper, 2016).

Study Gap: No such type of study done in Husain Abad community

\section{Problem Statement}

Poverty line of $\$ 1.90$ a day, World Bank projections suggest that global poverty may have reached 700 million, or 9.6 percent of global population, in 2015. The working poor, who work and live on less than $\$ 1.90$ a day, accounted for 10 percent of workers worldwide in 2015.(Ganguly et al., 2017)According to the World Bank, poverty in Pakistan $64.3 \%$ informs 2002 to $29.5 \%$ in 2014.(Muhammad et al., 2017) During wind shield survey noticed influence of poverty on the level of crime and poor moral development of individual's .these observations and the magnitude of moral problem will raise this research concern about poverty influence on moral development in Husain Abad community. Since there was no similar study about poverty influence on moral development so wants to fill this gap.

\section{Research Questions}

What is the relationship between poverty and moral development?

\section{Significance of Study}

a) After finding the influence of poverty on the moral development, the community people will

b) Be given an awareness education session.

c) They will be guide about the relationship of poverty and moral activities.

d) Counselling session will be plan for the community people.

e) Study will be important for Husain Abad community people to improve their moral values with in the limited resources.

f) Study will help me to enhance knowledge about poverty influence on moral development reasons and its effects on Husain Abad community people.

g) It opens the door for other researcher to conduct study on influence of poverty on moral development.

\section{Research Purpose}

The main purpose of the study is to assess the relationship of poverty and the moral development of community people.

\section{Research Objective}

Assess the relationship between poverty and moral development.

\section{Research Variables}

Independent Variable: Poverty

Dependent Variable: Moral development

\section{Research Hypothesis}

\section{Null Hypothesis:}

There is no significance relationship between poverty and moral development among community people 


\section{Alternative Hypothesis:}

There is significance relationship between poverty and moral development among community people.

\section{Theoretical Framework:}

Application on Kohlberg's Theory of Moral Development in Husain Abad community

According to Kohlberg's theory that human beings develop morals in stages, progressing consecutively from one stage to the next in an invariant sequence His model consists of three levels and six stages. These stages are extremely accurate, as well as useful, in understanding others' behavior from child to adult.

\section{Conceptual model about poverty influence on moral development:}

Conceptual model relate to the poverty influence on moral development .Low wages, estended family lead to the poverty and poverty effect on moral values. The six moral stages are group into three. (a) the pre-conventional level (stages one and two) which affects children under the age of nine and all other adolescents criminals or socially delinquent children, (b) the conventional level refers to stages three and four under which most adolescent of ages 10 to 25 belong, and (c) the post conventional level ,(stages five and six) affect the rest of the older ages in the society (Kohlberg, 1984). This last category is perceived to be the connection of morality and Social convention in a way, that social norms of the society have intrinsic ,moral rules and norms

\section{Conceptual Definition:}

Poverty:

Is the lack of necessities of economic life, money, material properties, and means of living.(Quarter, Ryan et al. 2014) Moral Development:

Moral is a socialized reasoning that develops as a result of the norms of a society and influenced by the culture of that society.(Verchick, 2012)

\section{Operational Definition:}

\section{Poverty:}

Poverty is about not having enough money to meet basic needs including food, clothing and shelter. Poverty is hunger. Poverty is lack of shelter. Poverty is being sick and not being able to see a doctor. Poverty is not having access to school and not knowing how to read. Poverty is not having a job, is fear for the future, living one day at a time.

Low Morality:

Personal and culturally values not well established among the people in community.

Highly Morality:

Personal and culturally values well established among the people in community.

\section{Literature Review}

Poverty has brought Pakistan face to face with a reality that it will find hard to accept: every third Pakistani caught in the 'poor' bracket i.e. some 58.7 million out of a total population of 180 million subsist below the poverty line. This includes more than half the population in the forever remote Baluchistan, 33 per cent in Sindh, 32 per cent in Khyber Pakhtunkhwa and 19 per cent in Punjab (Ahmad, 2013).

There is correlation between poverty and moral judgment of individuals in Nigeria., the researcher used the composite scores from the Likert chart and separated the scores for all variables of poverty from those of moral development. For poverty items, the overwhelming result was a confirmation of high poverty among the study population with an overall composite score of 4.56 for poverty items while 1.32 was the total composite score for moral development items. This means the higher the poverty level, the lower the moral development of the study population. Extended family dependency, low wages, and poor social services were also reasons for high poverty according to the study results (Omolade, 2016).

The effects particularly pronounced for children who live below the poverty line for multiple years and for children who live in extreme poverty (that is, $50 \%$ or less of the poverty threshold). These income effects are probably not due to some unmeasured characteristics of low-income families: family income, in and of itself, does appear to matter (Niragire, 2017).

There the following effects of poverty that occur on national level • Child labor in Pakistan • De track from moral and religious values $\bullet$ Crimes and violence $\bullet$ Health problems $\bullet$ Sub-standard lives.(Henricson 2016)

De-track from Moral and Religious values "No man can worship God or love his neighbor on an empty stomach." (Woodrow- T. Wilson) From the above quotation, we can very easily understand that what people are doing in the state of Poverty. They did not care of the Moral or Religious value. What is good for them is that which satisfy their needs and necessities. Crime and violence is the direct Effect of Poverty in Pakistan. The most common form of human handling is for prostitution (violence), which is largely drive by poverty. According to a survey most of poor men, violence on their wives for income purposes they force their women family members to earn something even by selling their bodies. Street crime is also the ultimate effect of Poverty in Pakistan(Lurigio and Herman 2012)

Pakistan is rank 135th out of 194 countries in the Index of Life Expectancy at the time of Birth. In Pakistan the life Expectancy rate at the time of Birth is very low i.e. 65 years. Whereas, in western countries it is $80+$ years i.e. Japan, Hong Kong, Australia, Switzerland, Iceland etc. $\neg$ Sub- 
standard lives By observing above factors one can very easily understand that overall Effect of Poverty in Pakistani Society is that, they are living Sub-Standard life.(Vousoura, 2014)

Youth Transitions and Crime found that poverty had a significant and direct effect on young people's likelihood to engage in violence at age 15 . Young people living in a family where the head of the household was unemployed were also more likely to participate in criminal behavior. Even poor individuals with "low risk" backgrounds were more likely to engage in violence. This means that types of young people, living in poor household increases their risk of engaging in violence beyond what one would expect. Poverty leads to dissatisfaction of individual's basic personal behavior.(Nelson and Taberrer, 2017)

\section{Methodology}

Study design: A co relational study design was use.

Site: Husain Abad community people

Setting: Houses of Husain Abad community where data collected.

Population: Study population for this research work were the people of Husain Abad community Lahore. The total number of people with moderate wages in Husain Abad community Lahore is 270 and number of people included with low wages in Husain Abad community is 168. Only low wages people are considered.

\section{Sample and size calculation:}

Sample size was determined by using the "Solvin's formula". This formula given as follows.

\section{Sample from Husain Abad community people:} $\mathrm{n}=\mathrm{N} / 1+\mathrm{N}(\mathrm{e})^{2}$

$(\mathrm{n})=$ sample size, $\mathrm{N}=$ Total population, $(\mathrm{e})=$ margin of error

$$
\begin{aligned}
& n=270 / 1+270(0.05)^{2} \\
& n=161
\end{aligned}
$$

\section{Sample from Husain Abad community Lahore door-to- door survey: $\mathrm{n}=\mathrm{N} / 1+\mathrm{N}(\mathrm{e})^{2}$}

$(n)=$ sample size, $N=$ Total population, $(e)=$ margin of error

$\mathrm{n}=\mathrm{n}=168 / 1+(168)(0.0025)$

$\mathrm{n}=118$

A small sample of $n=100$ was selected

\section{Sampling Method:}

Convenient sampling technique was use for the collection of data. This is non-probability sampling technique in which researcher selects subjects of his convenience and accessibility.
Inclusion Criteria:

Following people of Husain Abad community were included in data collection:

- Those who were present at the time of data collection

- Those who were willing to participate

- . People, who were 21-50 years old

\section{Exclusion Criteria:}

Following people from Husain Abad community will be not included in data collection:

- Those who were not present at the time of data collection

- Those who were not willing to participate

- People, who were less than 21 year and more than 50years old

\section{Data Collection Method:}

Self-prepared 5 point Likert scale questionnaire adapted from thesis of (Solomon Fakinlede, 2008).Following tools was use to get some basic information, which includes participant age, marital relationship, and family structure, no of children. The Poverty and Moral Development Survey Instrument was use to collect data. Items one through seven designed to measure participants' opinions on poverty while items eight through fifteen measured the level of moral development. First, this researcher assigned a numeric weight to each of the responses ( $1=$ Strongly Disagree, 2=Disagree, 3=Neutral, 4=Agree, and 5=Strongly Agree) and then, the scores were summed across moral development items and divide by the number of items.

\section{Data Analysis Method:}

After the collection of data, it was enter to Statistical Package for Social Sciences 21 (SPSS). Descriptive statistics were performing in the form of frequencies and percentages, which shown with the help of tables and graphs. Spears man Correlation analysis was apply to analyze the collected data in order to establish if the hypothesized relationships exist or not. The study measured the linear relationship between poverty and moral development.

\section{Ethical Consideration:}

Prior permission taken from the institution review board (IRB) and the authors of assessment tools, Informed consent of participant given with clear instruction Participants informed about the purpose and uses of the data collection. Participant privacy and confidentiality of information ensured. The information provided by the participant was use only for research purpose and not share. Respect for the dignity of research participants was prioritizing Participant allowed to withdraw from research at any time. 


\section{Data Analysis and Results}

Results and analysis of the Demographic data, Descriptive analysis of both Poverty and Moral development and the association in terms of correlation and regression between poverty and moral development through Pearson correlation has been described in following subheadings.

\section{Demographic data analysis and results}

Table 1 shows that $40 \%$ of the participants were age 21-30 years, $45 \%$ were age $31-40$ while $15 \%$ of the participants were from age 41-50 years. It also shows that 35 participants were males while $65 \%$ were Females. Similarly, 35\% participants belonged to nuclear family while $65 \%$ participants were from Joint families. Furthermore, $60 \%$ of the participants were having children less than $4,30 \%$ were having children $4-8$ while $10 \%$ of the study participants had more than 8 children.

Table 1: Frequency and percentage of demographics data

\begin{tabular}{|lll|}
\hline Variables & Number (n) & Percent \\
\hline Age & & \\
21-30 years & 40 & 40 \\
31-40 years & 45 & 45 \\
41-50 years & 15 & 15 \\
& & \\
Gender & & \\
Male & 35 & 35 \\
Female & 65 & 65 \\
& & \\
Family type & & 35 \\
Nuclear family & 35 & 65 \\
Joint Family & 65 & \\
$\quad$ & & 60 \\
Number of Children & & 30 \\
$\quad$ 1-4 & 60 & 10 \\
$\quad$ 4-8 & 30 & \\
$\quad$ Above 8 & 10 & \\
\hline
\end{tabular}

\section{Descriptive Analysis}

\section{Reliability Assessment}

Presents Cronbach's alpha for poverty and Moral development was use in the study (Table 2). Cronbach alpha is the most commonly used measure of scale reliability (Cortina, 1993). Cronbach alpha above 0.70 is considering the acceptable indicator of internal consistency reliability. Here the value for the poverty is .966 while for the morality is .70, which are acceptable in descriptive studies.

Table 2: Summary of Reliability assessment

\begin{tabular}{ll}
\hline Variables & Cronbach's alpha \\
\hline Poverty Questions & .966 \\
Moral Development & .70 \\
\hline
\end{tabular}

\section{Frequency and percentage of the poverty questions Agreements and Disagreements}

Table 3 shows that 55\% Agreed and 25\% strongly Agreed with statement that people having extended family members who sometimes or most of the times depend on them for financial support. When the participants were, ask that extended family dependency in society significantly increase poverty levels. The responses were that $50 \%$ agreed while $35 \%$ strongly agreed. Furthermore, $80 \%$ participants agreed and $15 \%$ strongly agreed that large family dependency is a factor of poverty. They were also asking whether poor wages is a cause of poverty where $90 \%$ of the respondents strongly agreed with the statement. On another question that is lack of adequate medical care contributes significantly to poverty in this society, $30 \%$ participants agreed and 65\% strongly agreed. $65 \%$ participants agreed and $25 \%$ strongly agreed that large-scale frauds in this society are contributing factors to poverty. $25 \%$ agreed while $75 \%$ strongly agreed poverty in any society is further aggravate by poor electric supply, poor road conditions, and grossly inadequate social support.

Table 3: Frequency and percentage of the Poverty

\begin{tabular}{|c|c|c|c|c|c|c|c|c|c|c|c|}
\hline \multirow{2}{*}{$\begin{array}{l}\text { S. } \\
\mathbf{N} .\end{array}$} & \multirow{2}{*}{ Statement } & \multicolumn{2}{|c|}{ SD } & \multicolumn{2}{|c|}{ DA } & \multicolumn{2}{|c|}{$\mathbf{N}$} & \multicolumn{2}{|c|}{$\mathbf{A}$} & \multicolumn{2}{|c|}{ SA } \\
\hline & & $\mathbf{N}$ & $\%$ & $\mathbf{N}$ & $\%$ & n & $\%$ & $\mathbf{N}$ & $\%$ & $\mathrm{n}$ & $\%$ \\
\hline 1 & $\begin{array}{l}\text { Most people have extended family members who sometimes or } \\
\text { most of the times depend on them for financial support. }\end{array}$ & 00 & 00 & 10 & 10 & 10 & 10 & 55 & 55 & 25 & 25 \\
\hline 2 & $\begin{array}{l}\text { Extended family dependency in this society significantly } \\
\text { increases poverty levels of an individual. }\end{array}$ & 00 & 00 & 5 & 5 & 10 & 10 & 50 & 50 & 35 & 5 \\
\hline 3 & $\begin{array}{l}\text { Large family dependency is a factor that increases inability of } \\
\text { individuals to meet their financial obligations }\end{array}$ & 00 & 00 & 00 & 00 & 5 & 5 & 80 & 80 & 15 & 15 \\
\hline 4 & $\begin{array}{l}\text { Poor wages is a major factor contributing to poverty in this } \\
\text { society. }\end{array}$ & 00 & 00 & 00 & 00 & 00 & 00 & 10 & 10 & 90 & 90 \\
\hline 5 & $\begin{array}{l}\text { Lack of adequate medical care contributes significantly to poverty } \\
\text { level in this society. }\end{array}$ & 00 & 00 & 00 & 00 & 5 & 5 & 30 & 30 & 65 & 65 \\
\hline 6 & $\begin{array}{l}\text { Large-scale fraud and financial mismanagement in this society are } \\
\text { contributing factors to poverty. }\end{array}$ & 00 & 00 & 00 & 00 & 10 & 10 & 65 & 65 & 25 & 25 \\
\hline 7 & $\begin{array}{l}\text { Poverty in this society further aggravated by poor electricity } \\
\text { supply, poor road conditions, and grossly inadequate social } \\
\text { services }\end{array}$ & 00 & 00 & 00 & 00 & 5 & 5 & 25 & 25 & 70 & 70 \\
\hline
\end{tabular}




\section{Frequency and Percentage of Moral development Questionnaire Agreements and Disagreements:}

Table 4 shows that $60 \%$ Agreed and $20 \%$ strongly agreed with statement that people engage in fraud, do not know their actions are wrong. When the participants were, ask that Honesty and truthfulness depend poor financial status of the people; the responses were that $60 \%$ Disagreed, $15 \%$ neutral, while $25 \%$ agreed. Furthermore, $60 \%$ participants agreed and $30 \%$ strongly agreed that when people are poor their levels of financial honesty are negatively affected. They were also asking whether High level of indebtedness of an individual does not affect the level of financial honesty where $65 \%$ of the respondents agreed and $25 \%$ strongly agreed with the statement. On another question that is that lack of financial abilities to acquire the necessities of life is contributing factor to dishonesty or fraud, $65 \%$ participants agreed and 30\% strongly agreed. $80 \%$ participants agreed and $15 \%$ strongly agreed that anyone who deceived you once in the past because of his/her poor financial situations is likely to deceive you again even if his situation has not improved. $25 \%$ agreed while $75 \%$ strongly agreed that entrusting huge financial responsibilities on a poor individual might lead to risk of fraud. $80 \%$ agreed while $20 \%$ strongly agreed that poverty affects the level of honesty of individuals in financial contract or deals.

\section{Descriptive Analysis of Poverty Tool Individual Items}

The Fig. 1 reveals that $55 \%$ participants agreed that extended family members mostly depends on financial support from one bread earners, while $25 \%$ strongly agreed with the statements.

The Fig. 2 suggests that almost $85 \%$ of the participants are with the agreement that extended family dependency further increases the level of poverty among the people of that nation or society

The Fig. 3 shows that a large number of participants that is $80 \%$ agreed that large family is a leading factor of increasing inability to meet financial needs, while $15 \%$ participants agreed with it.

Table 4: Frequency and Percentage of Moral Development

\begin{tabular}{|c|c|c|c|c|c|c|c|c|c|c|c|}
\hline \multirow{2}{*}{$\begin{array}{l}\text { S. } \\
\text { N. }\end{array}$} & \multirow[t]{2}{*}{ Statement } & \multicolumn{2}{|c|}{ SD } & \multicolumn{2}{|c|}{ DA } & \multicolumn{2}{|c|}{$\mathbf{N}$} & \multicolumn{2}{|c|}{$\mathbf{A}$} & \multicolumn{2}{|c|}{ SA } \\
\hline & & $\mathbf{N}$ & $\%$ & $\mathbf{N}$ & $\%$ & $\mathbf{n}$ & $\%$ & $\mathbf{N}$ & $\%$ & $\mathbf{n}$ & $\%$ \\
\hline 1 & $\begin{array}{l}\text { In this society, people engage in fraud, embezzlement, they do } \\
\text { not know their actions are wrong. }\end{array}$ & 00 & 00 & 10 & 10 & 10 & 10 & 60 & 60 & 20 & 20 \\
\hline 2 & Honesty and truthfulness depend poor financial & 00 & 00 & 60 & 60 & 15 & 15 & 25 & 25 & 00 & 00 \\
\hline 3 & $\begin{array}{l}\text { When people are poor their levels of financial honesty are } \\
\text { negatively affected }\end{array}$ & 00 & 00 & 5 & 5 & 5 & 5 & 60 & 60 & 30 & 30 \\
\hline 4 & $\begin{array}{l}\text { High level of indebtedness of an individual does not affect the } \\
\text { level of financial honesty }\end{array}$ & 00 & 00 & 00 & 00 & 10 & 10 & 65 & 65 & 25 & 25 \\
\hline 5 & $\begin{array}{l}\text { Lack of financial abilities to acquire the necessities of life is } \\
\text { contributing factor to dishonesty or fraud. }\end{array}$ & 00 & 00 & 00 & 00 & 5 & 5 & 65 & 65 & 30 & 30 \\
\hline 6 & $\begin{array}{l}\text { In this society, not anyone who deceived you once in the past } \\
\text { because of his /her poor financial situations is likely to deceive } \\
\text { you again even if his situation has not improved. }\end{array}$ & 00 & 00 & 00 & 00 & 5 & 5 & 80 & 80 & 15 & 15 \\
\hline 7 & $\begin{array}{l}\text { Entrusting huge financial responsibilities on a poor individual } \\
\text { may lead to risk of fraud }\end{array}$ & 00 & 00 & 00 & 00 & 00 & 00 & 25 & 25 & 75 & 75 \\
\hline 8 & $\begin{array}{l}\text { Considering your knowledge of this society, poverty does not } \\
\text { affect the level of honesty of individuals in financial contract or } \\
\text { deals. }\end{array}$ & 00 & 00 & 00 & 00 & 00 & 00 & 80 & 80 & 20 & 20 \\
\hline
\end{tabular}




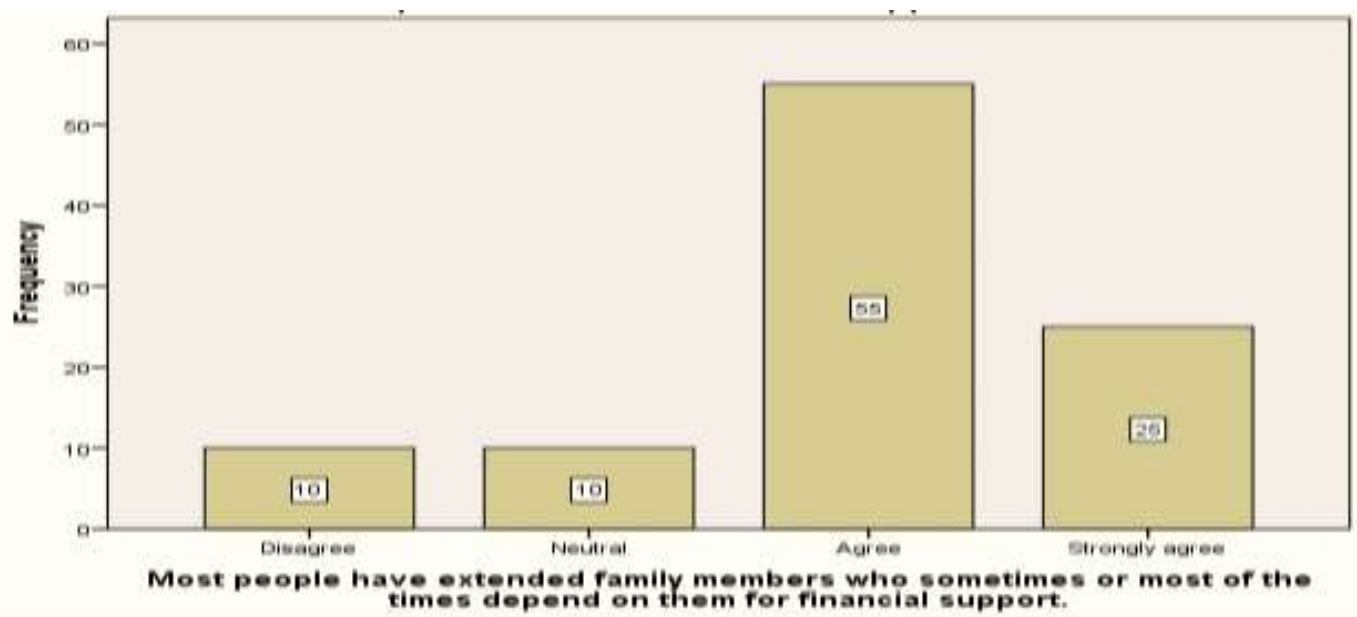

Fig. 1: Graph showing extended family members depends on financial support.

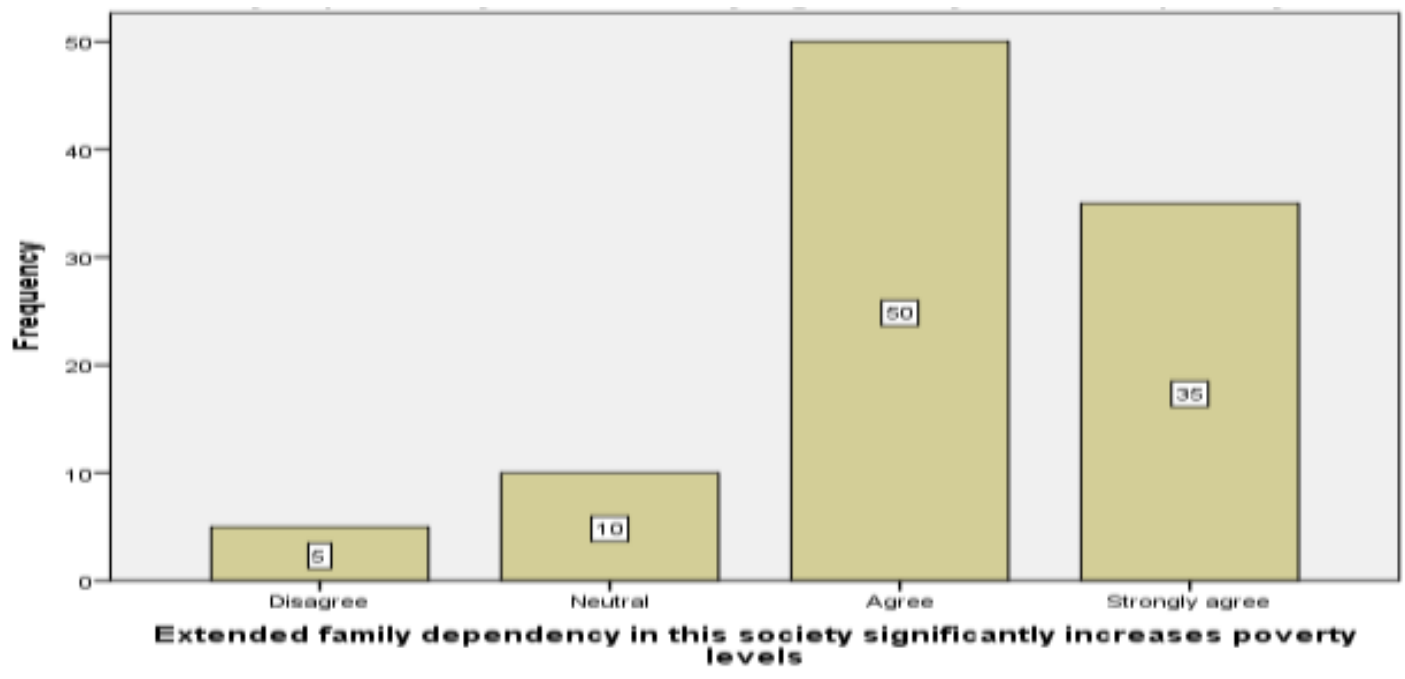

Fig. 2: Effect of extended family dependency on poverty.

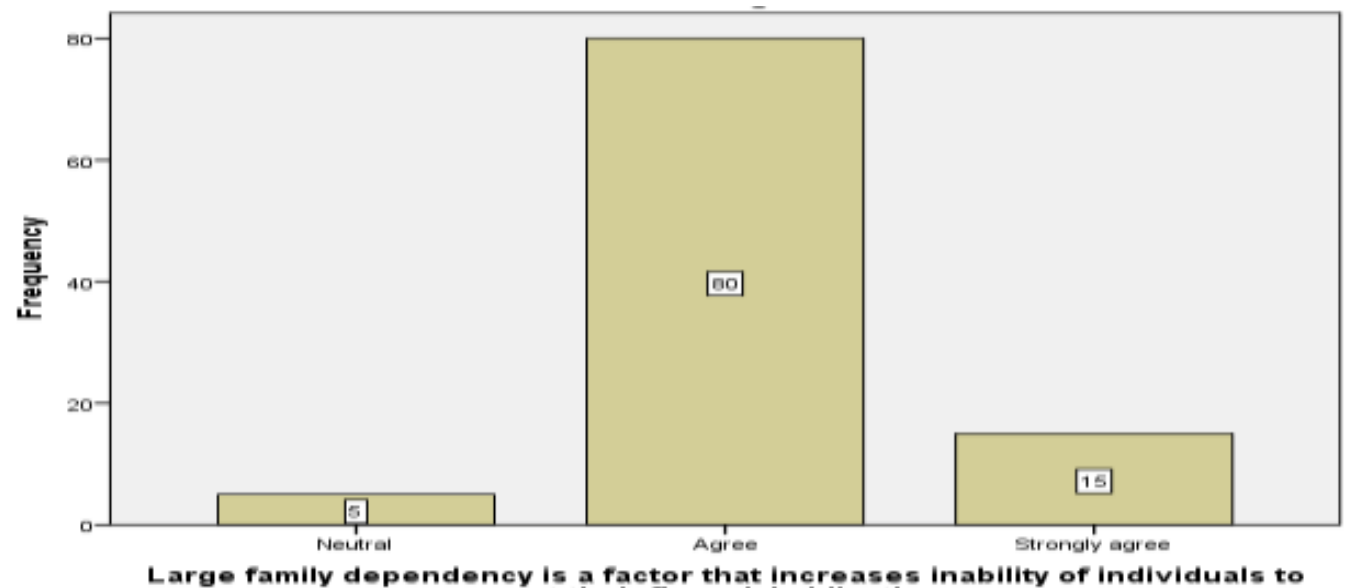

Large family dependency is a factor that increases in
meot their finanoial obligations.

Fig. 3: Large family is a leading factor of increasing poverty.

Fig. 4 reveals that $90 \%$ participants agreed that poor wages is the main cause of poverty in any society.

The Fig. 5 shows that $65 \%$ of the study participants agreed that lack of medical care facilities contributes to poverty in a society, $30 \%$ remained neutral while $5 \%$ disagree with the statement
When it was ask whether frauds and financial mismanagement in a society contributes to poverty, $65 \%$ participants agreed and $25 \%$ strongly agreed with the statement (Fig. 6). 


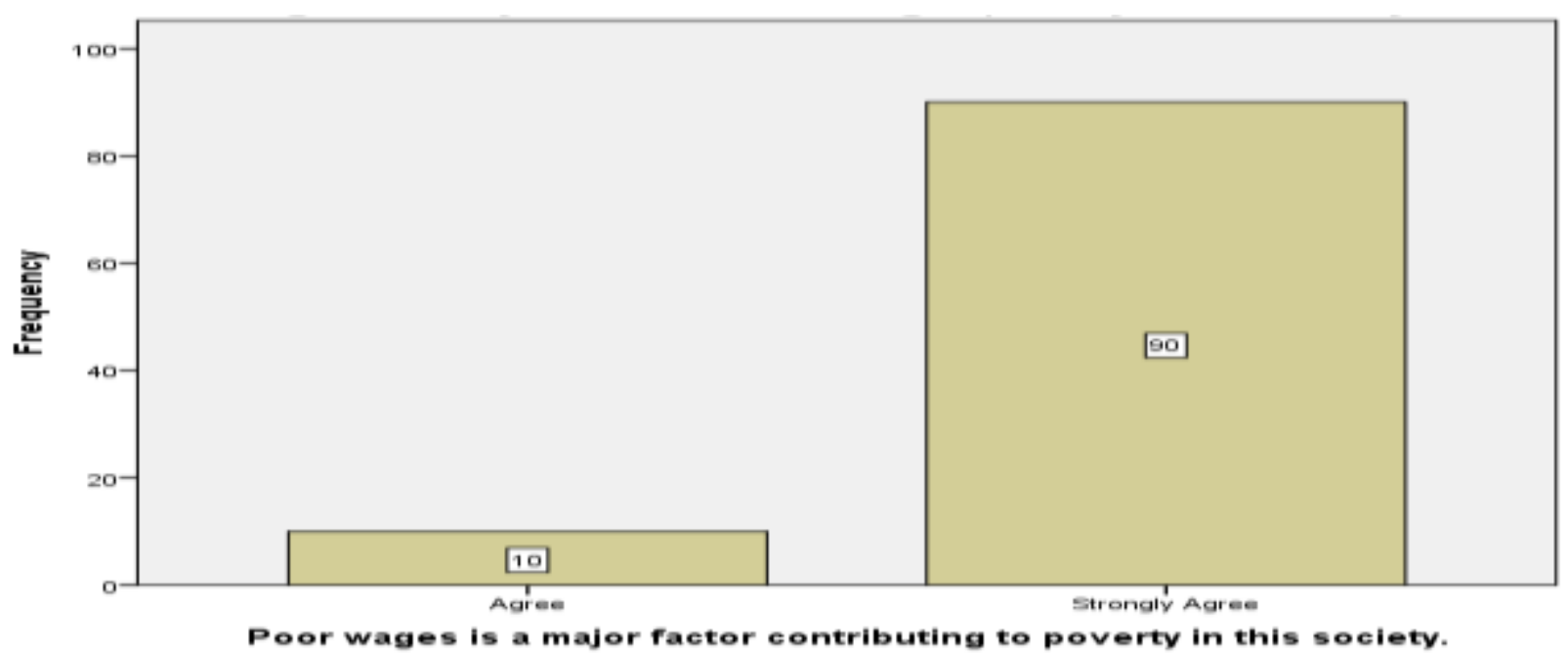

Fig. 4: Poor wages is a major factor for poverty in the society.

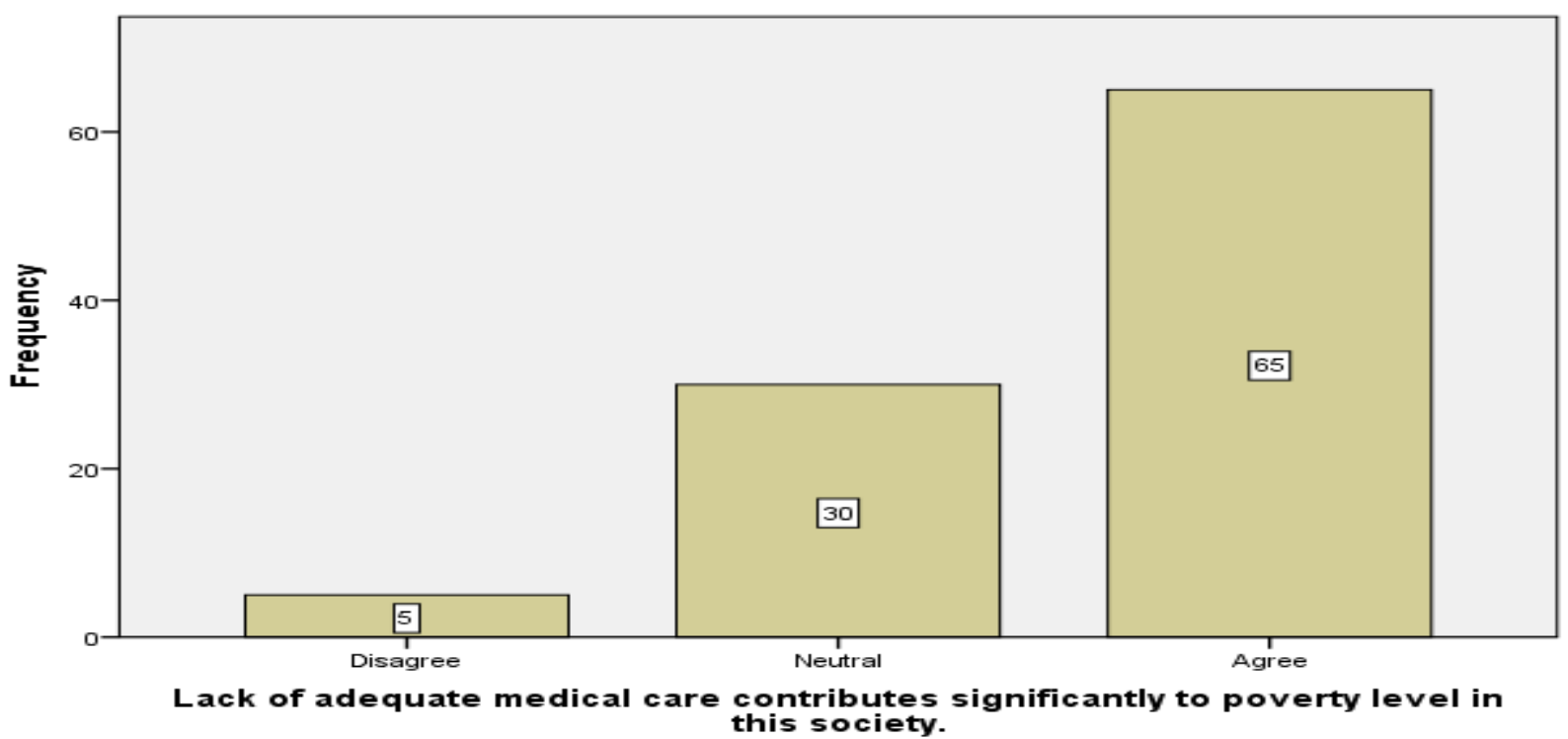

Fig. 5: Lack of medical care facilities contributes to poverty.

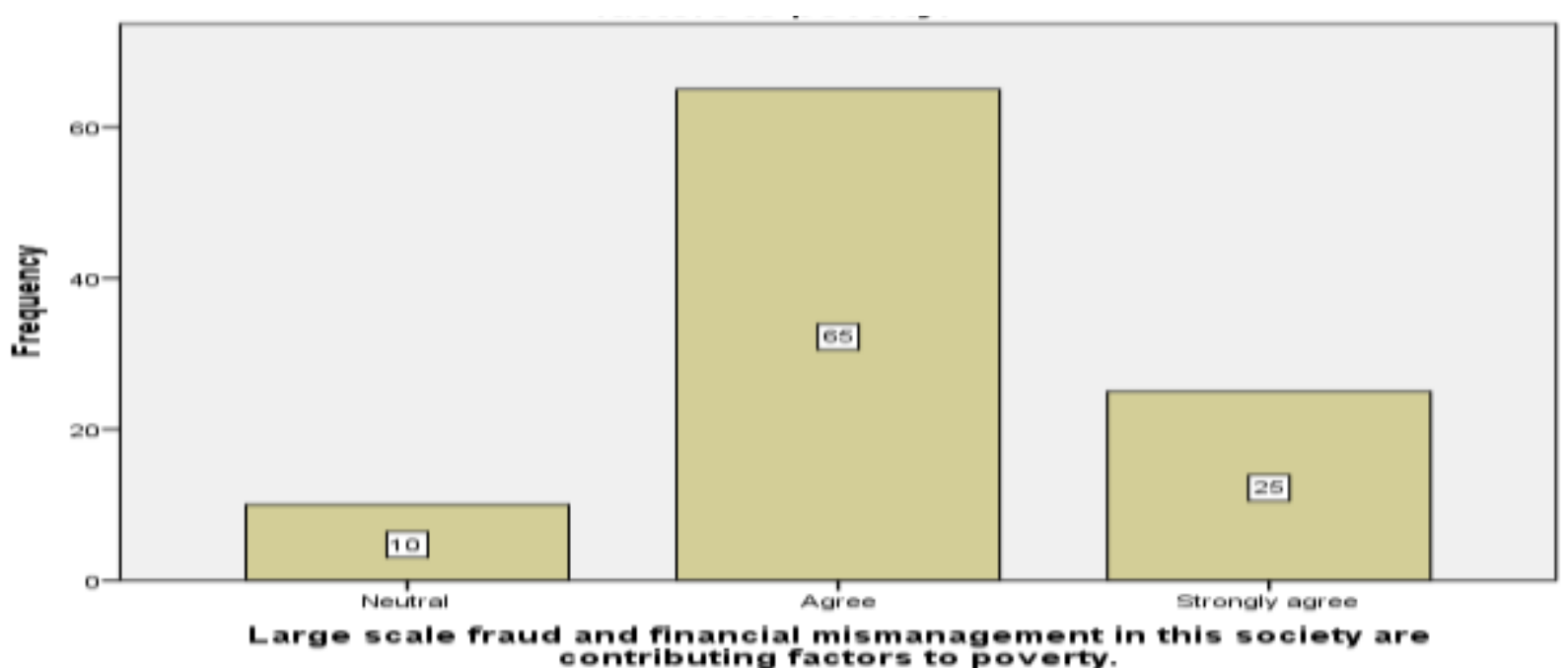

Fig. 6: Frauds and financial mismanagement in a society contributes to poverty. 
The Fig. 7 shows overall about $90 \%$ of the study participants agreed upon that in poor and low financial conditions does not affect their financial honesty.

The Fig. 8 reveals that $65 \%$ participants agreed that lack of financial abilities and necessities do not affect or contribute to dishonesty and frauds, while $30 \%$ strongly agreed.

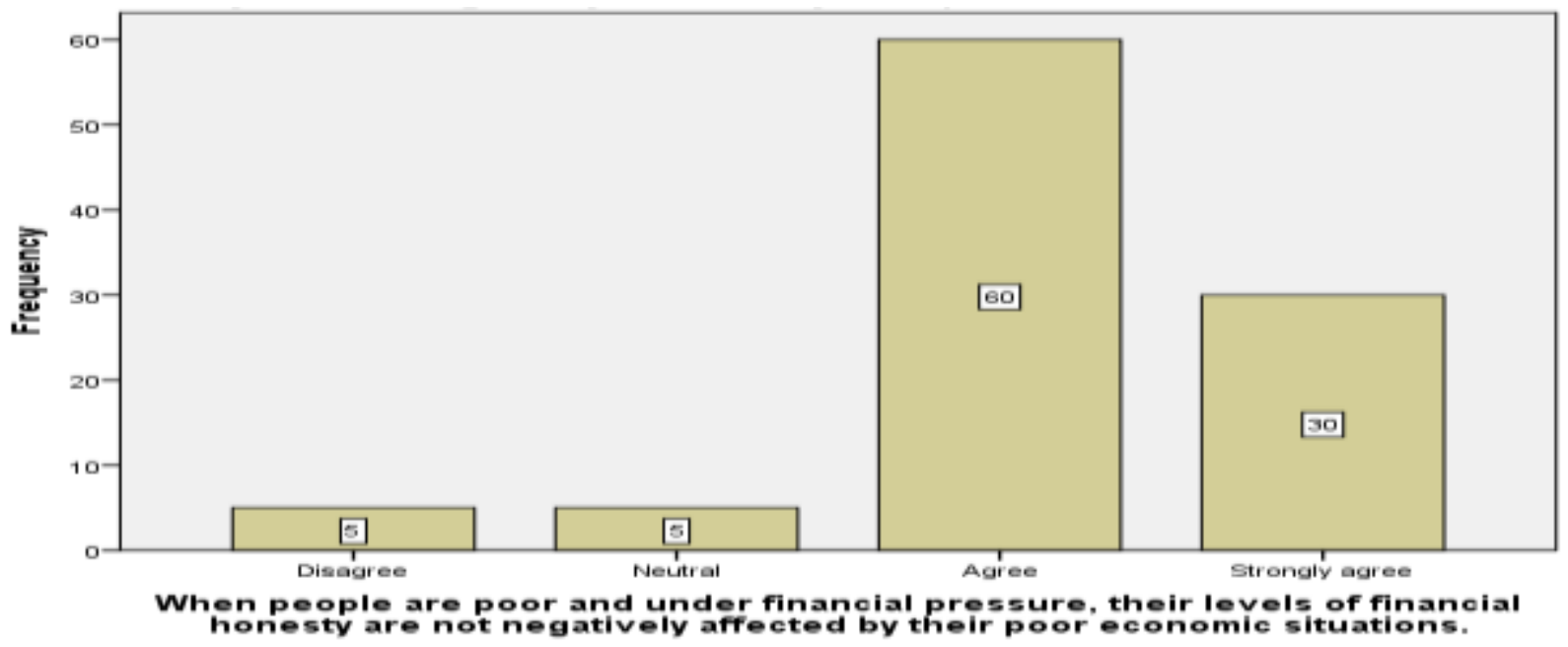

Fig. 7: Poor and low financial conditions does not affect their financial honesty

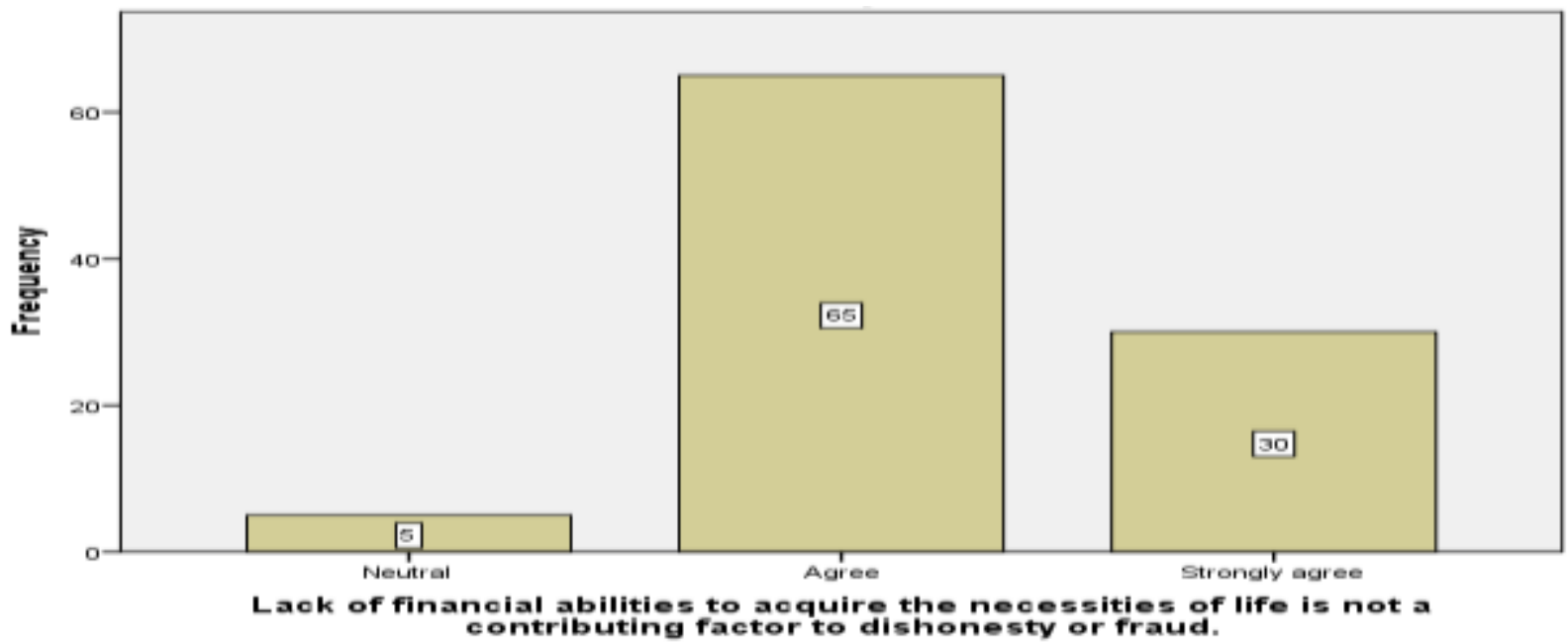

Fig. 8: Financial abilities and necessities do not affect or contribute to dishonesty and frauds

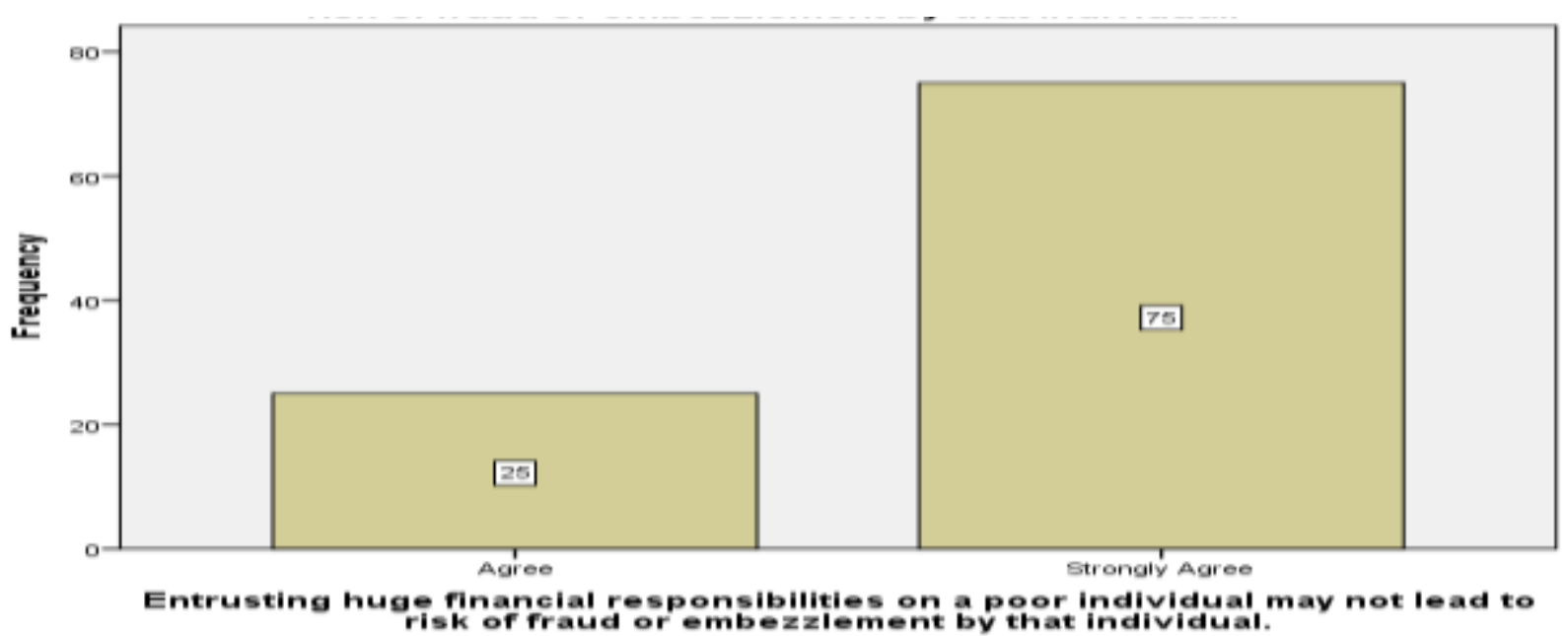

Fig. 9: Huge financial responsibilities on poor individual may not lead to risk of fraud. 


\section{Correlational Analysis of Poverty and moral Development}

The Fig 10- shows scattered plot that there is a strong positive linear correlation between the poverty score and the moral development score.

The normality test shows that the Shapiro wilk test values are less than 0.05 , which indicates that the data is not normally distribute therefore, the Pearson's correlation is not suitable and a nonparametric test the spears man correlation will be applied (Table 5.)

The Table 6 reveals that the coefficient of correlation rs value of the spears man correlation test is 0.939 , which suggest that there is a positive, strong, linear correlation between the poverty and moral development.

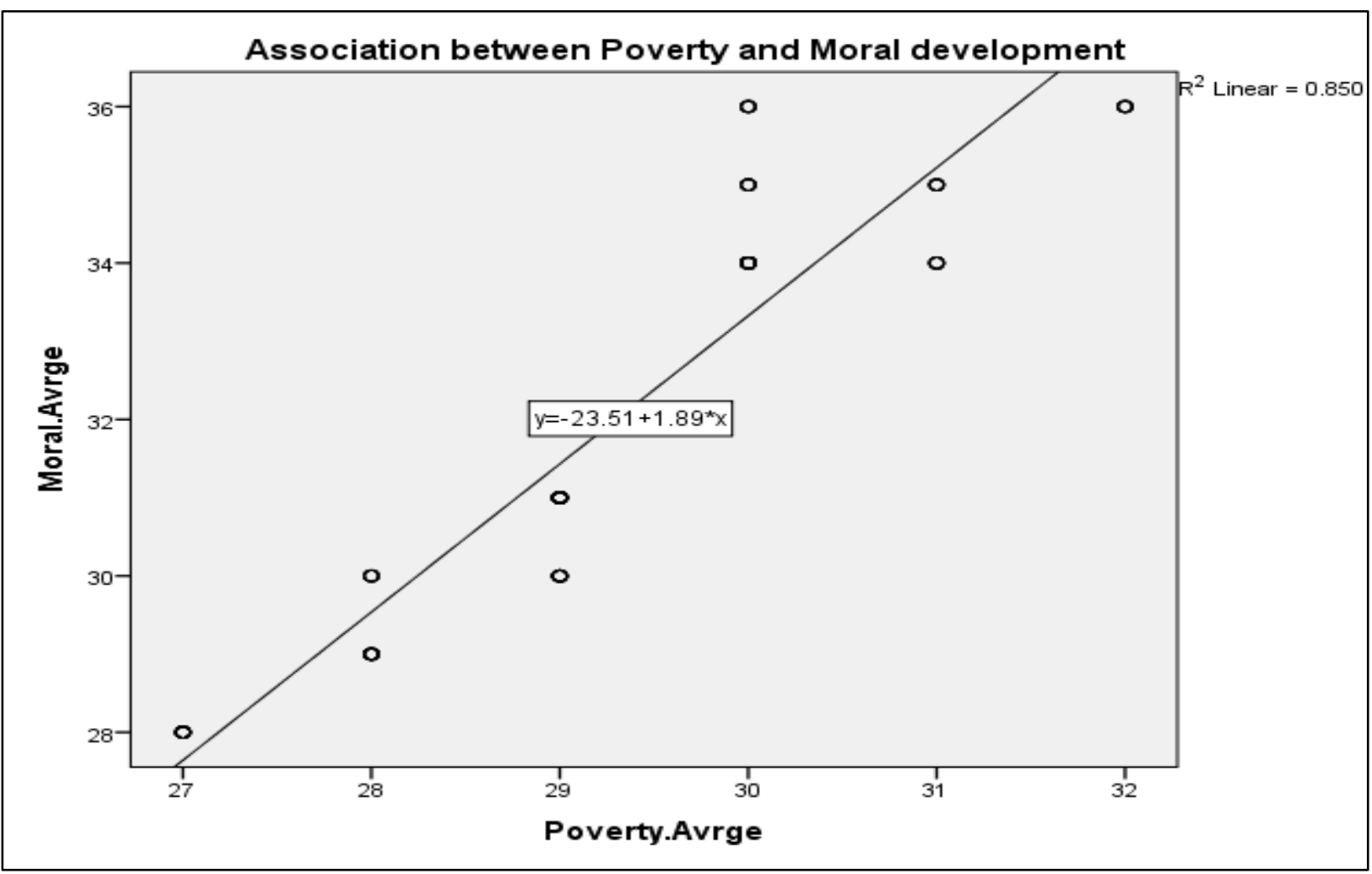

Fig. 10: Scattered plot showing strong positive linear correlation between the poverty score and the moral development score

Table 5: Test of normality

\begin{tabular}{lllllll}
\hline & \multicolumn{5}{c}{ Tests of Normality } \\
& \multicolumn{1}{c}{ Kolmogorov-Smirnov $^{\mathrm{a}}$} & \multicolumn{3}{c}{ Shapiro-Wilk } \\
\cline { 2 - 7 } Poverty Score & Statistic & $\mathrm{df}$ & Sig. & Statistic & df & Sig. \\
Moral Score & .158 & 100 & .000 & .933 & 100 & .000 \\
\hline
\end{tabular}

Table 6: Spears Man test of Correlation

\begin{tabular}{|c|c|c|c|c|}
\hline \multicolumn{5}{|c|}{$\begin{array}{l}\text { Spears Man Correlations } \\
\end{array}$} \\
\hline & & & Poverty.Avrge & Moral.Avrge \\
\hline \multirow{6}{*}{ Spearman's rho } & \multirow{3}{*}{ Poverty.Avrge } & Correlation Coefficient & 1.000 & $.939^{* *}$ \\
\hline & & Sig. (2-tailed) & . & .000 \\
\hline & & $\mathrm{N}$ & 100 & 100 \\
\hline & \multirow{3}{*}{ Moral.Avrge } & Correlation Coefficient & $.939^{* *}$ & 1.000 \\
\hline & & Sig. (2-tailed) & .000 & . \\
\hline & & $\mathrm{N}$ & 100 & 100 \\
\hline
\end{tabular}

**. Correlation is significant at the 0.01 level (2-tailed). 


\section{Discussion}

In this study, there are a large number of participants more than $90 \%$ who agreed that extended family dependency and large family etcetera are factors leading to poverty among the society and which has an effect on the overall moral development of the people. Then they do not care of the Moral or Religious value. What is good for them is that which satisfy their needs and necessities. Crime and violence is the direct Effect of Poverty in Pakistan. The most common form of human handling is for prostitution (violence), which largely driven by poverty. According to a survey, most of poor men violence on their wives for income purposes and force their women family members to earn something even by selling their bodies. Street crime is also the ultimate effect of Poverty in Pakistan (Lurigio and Herman, 2012). De-track from Moral and Religious values "No man can worship God or love his neighbor on an empty stomach." (Woodrow- T. Wilson) From the above quotation, we can very easily understand that what people are doing in the state of Poverty.

During this current study, a significant positive correlation found between poverty and moral development. There is a strong correlation between them evidenced by such a high value of spears man coefficient of determination which is ( $r s=939)$ indicates that there is high correlation between the poverty and moral development. According to a study, there is correlation between poverty and moral judgment of individuals in Nigeria., the researcher used the composite scores from the Likert chart and separated the scores for all variables of poverty from those of moral development. For poverty items, the overwhelming result was a confirmation of high poverty among the study population with an overall composite score of 4.56 for poverty items while 1.32 was the total composite score for moral development items. This means the higher the poverty level, the lower the moral development of the study population. Extended family dependency, low wages, and poor social services were also reasons for high poverty according to the study results. (Omolade, 2016)

Another study also found that there is correlation between poverty and moral judgment of individuals in Nigeria. , the researcher used the composite scores from the Likert chart and separated the scores for all variables of poverty from those of moral development. For poverty items, the overwhelming result was a confirmation of high poverty among the study population with an overall composite score of 4.56 for poverty items while 1.32 was the total composite score for moral development items. This means the higher the poverty level, the lower the moral development of the study population. Extended family dependency, low wages, and poor social services were also reasons for high poverty according to the study results.(Akinlabi, 2017)

\section{Conclusion}

In conclusion, it stated that this research study found the relationship between the poverty and moral development in a society. The results revealed that there is a strong positive correlation between the poverty and moral development of the people. Moreover, some factors such as large family size, extended family, family dependency ratio and low wages etcetera were study and they found to be the leading factors in poverty.

\section{Limitations of the Study:}

Limitations of the study were following

- Sample size $\mathrm{n}=100$, which is low and cannot be generalized to the larger population

- There was very short time to conduct this study, which can leads to some scientific and methodological mistakes

\section{Recommendation}

Poverty is very dangerous for any nation, which make children and youth criminals in many ways. People may not have access to quality health care, good education and necessities of life. Therefore, there is a need for any country, society to improve the wages of labour, provide more job opportunities to the lower class of the state. More studies should be conduct to find the actual status of poverty in the whole country.

\section{Acknowledgement}

The first author would like to thanks to all persons of Lahore School of nursing (LSN), The University of Lahore who directly helped during study.

\section{References}

Ahmad TI (2013). The role of rural women in livestock management: socio-economic evidences from diverse geographical locations of Punjab (Pakistan), Université Toulouse le Mirail-Toulouse II.

Aiyedogbon JO and Ohwofasa BO (2012) Poverty and youth Unemployment in Nigeria, 1987-2011. International Journal of Business and Social Science 3(20).

Akinlabi OM (2017) Young people, procedural justice and police legitimacy in Nigeria. Policing and Society 27(4): 419438.

Ballard MS (2017) Integrating Forgiveness Therapy and the Treatment of Anger: A Randomized Controlled Trial, University of Denver.

Bandyopadhyay M (2017) Education, Poverty and Exclusion, Retrieved.

Bradshaw J and Main G (2016) Child poverty and deprivation. The Wellbeing of Children in the UK: 31.

Crettaz E and Suter C (2013) The impact of adaptive preferences on subjective indicators: An analysis of poverty indicators. Social Indicators Research 114(1): 139-152. 
Dana LP and Galbraith CS (2016) The Empirical Research. Social and Moral Values: Individual and Societal Perspectives: 87.

Dickerson A and Popli GK (2016) Persistent poverty and children's cognitive development: evidence from the UK Millennium Cohort Study. Journal of the Royal Statistical Society 179(2): 535-558

Donnelly J and Whelan DJ (2017) International human rights, Westview Press.

Ganguly K, Gulati A and von Braun J (2017). Innovations Spearheading the next Transformations in India's Agriculture.

Gasper D (2016) Ethics of development.

Gibbs JC (2013) Moral development and reality: Beyond the theories of Kohlberg, Hoffman, and Haidt. Oxford University Press.

Hallett N (2016) Lives of Spirit: English Carmelite Self-Writing of the Early Modern Period, Routledge.

Henricson C (2016) Morality and public policy. Policy Press.

Lin J (2016). Influences of caregivers' cultural norms, values, beliefs and experiences on caregiver physical aggression. University of California, Irvine.

Lurigio AJ and Herman S (2012) Victims of crime. Sage.

Metz T (2016) The Nature of Poverty as an Inhuman Condition. Res Publica 22(3): 327-342.

Muhammad L, Mahadi B and Hussin N (2017) Influence of social capital on customer's relationship satisfaction in the Pakistani banking industry. Asia Pacific Journal of Marketing and Logistics 29(5): 1036-1054.

Naqvi I and Kamal A (2013) Personality Traits predicting the Delinquency among Laborer Adolescents. FWU Journal of Social Sciences 7(1): 15.

Narvaez D and Lapsley D (2014) Becoming a moral person-Moral development and moral character education as a result of social interactions. Empirically informed ethics: Morality between facts and norms, Springer: 227-238.

Nash TML (2016) Life in the Shadows: Examining the Role that HIV Status Plays in the Decision Making Processes of
HIV Positive Aboriginal Women in Terms of Their Reproductive Health and Their Decisions to Have a Child or Not, University of Calgary.

Nelson P and Taberrer S (2017) Hard to reach and easy to ignore: the drinking careers of young people not in education, employment or training. Child \& Family Social Work 22(1): 428-439.

Niragire F (2017) Spatial modelling of the relationship between $H I V$ prevalence and determinants of child mortality in Rwanda. University of Rwanda.

Omolade OO (2016) Effects of Civic Skills and Value Clarification Training on Moral Reasoning among Secondary School Students in Ibadan Metropolis, Nigeria.

Quarter J, Ryan S and Chan A (2014). Social purpose enterprises: Case studies for social change, University of Toronto Press.

Ross AM (2017) An Examination of Poverty: A Case Study of One Rural Missouri School Attempting to Meet the Needs of All Students, Lindenwood University.

Seidman S (2016) Contested knowledge: Social theory today. John Wiley \& Sons.

Thompson P (2017) Environmental Justice: International Discourses in Political Economy. Routledge.

Trani JF and Bakhshi P (2017) A Multidimensional Approach to Poverty: Implications for Global Mental Health. The Palgrave Handbook of Sociocultural Perspectives on Global Mental Health, Springer: 403-428.

Venera Z and Zakus D (2016) Barriers to Poverty Reduction in Russia: Participatory Qualitative Assessment. Oxfam GB Case Study. J Comm Pub Health Nursing 2(109): 2.

Verchick RR (2012) Disaster Justice: The Geography of Human Capability.

Vousoura E (2014) Psychological distress among mothers of young children in rural Ghana and Uganda and its association with child health and nutritional status, Columbia University.

Xun Z and Lubrano M (2017) A Bayesian Measure of Poverty in the Developing World. Review of Income and Wealth. 